\title{
A Study on Psychological Problems Faced by the Parents of Autism Children
}

Kalaivnai P and Kali M Kalimo*

Department of Social Science Extension Education, Avinashilingam Institute for Home Science and Higher Education for Women, Coimbatore, Tamil Nadu, India

\begin{abstract}
Autism is a neuro-developmental disorder identified by impaired communication and social interaction and repetitive behaviors. It is more challenging for the parents to take care of their ASD children and it also affects their family life. The main objectives of the study is analyze the problem faced by parents of autism children, assess the level of stress faced by the parents of autism children and asses the level of adjustment among the parents of autism children. The total sample size fifty (18 fathers and 32 mothers of autism Children) was drawn from Mind Matters in Vilankurichi and AIM in New Siddhapudhur, Coimbatore District, Tamil Nadu. Simple random sampling techniques were used to select the sample for study. Primary data were collected from 50 parents of the autism children. There were 32 per cent had a score of less than 48 (low level of stress), about 44 per cent had a score between 48 and 57 (moderate level of stress), and the left 24 per cent had a score of greater than 57 (high level of stress). The range of score indicates that both mothers and fathers were facing moderate level of stress due to their autism child. It was concluded that parent's ability and confidence in their competence of parenting a child in challenging situations may reduce their stress to a limited extent.
\end{abstract}

\section{Keywords: Social; Parents; Health; Children; Education}

\section{Introduction}

Autism is a neuro-developmental disorder identified by impaired communication and social interaction and repetitive behaviors. The genetic, environmental, and immunological factors play an important role for the causes of autism spectrum disorder as indicated by several researches [1]. It is more challenging for the parents to take care of their ASD children and it also affects their family life. There was a higher level of parenting stress among parents of ASD children than parents of normal or ordinary children and children with other kinds of disabilities as strongly insisted [2]. Given that chronic stress can had more bad effects on a range of physical as well as psychological wellbeing [3], the parents of ASD children had also been found to report poorer health and more illnesses than parents of normal or ordinary children and children with other kinds of disabilities it was perhaps not a surprising one [4-7].

The main objectives of the study is to:

1. Analyze the problem faced by parents of autism children

2. Assess the level of stress faced by the parents of autism children and

3. Asses the level of adjustment among the parents of autism children.

\section{Methodology}

The total sample size fifty (18 fathers and 32 mothers of autism Children) was drawn from Mind Matters in Vilankurichi and AIM in New Siddhapudhur, Coimbatore District, Tamil Nadu. Simple random sampling techniques were used to select the sample for study. Primary data were collected from 50 parents of the autism children. The independent and dependent variables were identified, based on the data collected from the respondents. The independent variables such as Age, Sex, Educational Qualification, Community, Religion, Occupation, Monthly Income and Type of Family were measured with the actual information of the respondents. The dependent variables such as parental stress level, parental adjustment and concern level were measured with Parental Stress Scale Parenting and Family Adjustment Scales (PAFAS) and problems of the children were measured with the scale developed for the study. The collected data were consolidated, analysed and presented in Results and Discussion.

\section{Results and Discussion}

\section{Socio economic profile of the respondents}

The socio economic profile of the respondents is presented in Table 1.

Sex: Table 1 revealed that the majority of the genders of parents with autistic children (64 per cent) respondents were female (mother).

Age: Regarding the age wise distribution 34 per cent of the respondents were comes under the age group of 20-30 years, whereas 62 per cent were comes under 31-40 years of age and the remaining 4 per cent were fall under the age of 41 and above.

Educational qualification: A majority of 68 percent of the respondents had education up to graduate, 12 percent of the respondents had finished their higher secondary school level, 12 per cent of the respondents were completed their primary and high school level and least 8 per cent of the respondent were illiterate.

Community: The backward class (BC) dominated as the respondents of the study 80 percent, followed by 10 per cent of them belonging to $\mathrm{OC}, 8$ per cent were of them belonging to $\mathrm{MBC}$ and two percent of the respondents were SC.

${ }^{*}$ Corresponding author: Kalimo KM, Department of Social Science Extension Education, Avinashilingam Institute for Home Science and Higher Education for Women, Coimbatore, Tamil Nadu, India, Tel: +91-8608369425; E-mail: pkvani12@gmail.com

Received June 06, 2018; Accepted June 20, 2018; Published June 26, 2018

Citation: Kalaivnai P, Kalimo KM (2018) A Study on Psychological Problems Faced by the Parents of Autism Children. Arts Social Sci J 9: 376. doi: 10.4172/21516200.1000376

Copyright: (c 2018 Kalaivnai $P$, et al. This is an open-access article distributed under the terms of the Creative Commons Attribution License, which permits unrestricted use, distribution, and reproduction in any medium, provided the original author and source are credited. 


\begin{tabular}{|c|c|}
\hline Aspects & $\begin{array}{l}\text { Percentage of the Respondents } \\
\text { (N: } 50)\end{array}$ \\
\hline \multicolumn{2}{|l|}{ Age (in years) } \\
\hline $20-30$ & 34 \\
\hline $31-40$ & 62 \\
\hline 41 and above & 4 \\
\hline \multicolumn{2}{|l|}{ Gender } \\
\hline Male (Father) & 36 \\
\hline Female (Mother) & 64 \\
\hline \multicolumn{2}{|l|}{ Educational qualification } \\
\hline Illiterate & 8 \\
\hline Primary Education & 6 \\
\hline High School & 6 \\
\hline Higher Secondary & 12 \\
\hline Graduate & 68 \\
\hline \multicolumn{2}{|l|}{ Community } \\
\hline OC & 10 \\
\hline$B C$ & 80 \\
\hline MBC & 8 \\
\hline SC & 2 \\
\hline \multicolumn{2}{|l|}{ Religion } \\
\hline Hindu & 86 \\
\hline Christian & 10 \\
\hline Muslim & 4 \\
\hline \multicolumn{2}{|l|}{ Occupation } \\
\hline House wife & 42 \\
\hline Business & 6 \\
\hline Private Employer & 18 \\
\hline Government employer & 20 \\
\hline Daily wages & 14 \\
\hline \multicolumn{2}{|l|}{ Monthly income (in Rs) } \\
\hline $2,000-5,000$ & 14 \\
\hline $5,000-10,000$ & 16 \\
\hline $15,000-20,000$ & 18 \\
\hline $20,000-25,0000$ & 10 \\
\hline Not applicable & 42 \\
\hline \multicolumn{2}{|l|}{ Type of family } \\
\hline Joint family & 38 \\
\hline Nuclear family & 62 \\
\hline
\end{tabular}

Table 1: Socio-Economic profile of the respondents.

Religion: The present study highlights the facts that 86 percent of the respondents were Hindus, 10 per cent of them were under the categories of Christian, and only 4 percent were under the categories of Muslim.

Occupation: Regarding the occupation of the respondents, it was seen that nearly half of the respondents ( 42 per cent) were house wives, since they have to take care of their children followed by 18 per cent were private employers and 20 per cent were government employers respectively, 14 per cent were belonged to the daily wage groups and the left 6 per cent were business persons.

Income: Around 50 respondents 14 per cent were earning income between Rs.5,000-10,000/- per month, whereas 16 per cent of them were earning in the range between 10,000-15,000 rupees, while 18 per cent were earning from $15,000-20,000$ rupees, only 10 per cent were earning from 20,000-25,000. The non-earning income group consists of 21 women.

Type of family: Over the 50 respondents majority of the respondents ( 62 per cent) were belonged to the nuclear family and the other 38 per cent were belonged to the joint family.

\section{Difficulties faced by the parents due to their autism children}

The various difficulties faced by the parents due to their autism children are presented in Table 2. Out of the 50 parents of such children, 80 per cent of parents were having problem in finding the right school or right type of education. Travel safely and independently begin or maintain a friendship or a relationship was a problem for 52 per cent of the parents with their autistic children and enjoying leisure and recreational opportunities was a problem for with their autism children. About 48 per cent of parents were having problem from school to college or in to employment with their autism children. 40 per cent of the parents were having problem in maintaining a balanced healthy and nutritious diet for their autism children.

\section{Level of stress faced by the parents of autism children}

The level of stress faced by the parents of autism children is presented in Table 3. Sixteen respondents (32 per cent) had a score of less than 48 (low level of stress), twenty two respondents (44 per cent) had a score between 48 and 57 (moderate level of stress), and twelve respondents ( 24 per cent) had a score of greater than 57 (high level of stress). The range of scores in the present study shows that mothers and fathers reported that they are facing moderate level of stress because of their autism child. For a visual depiction of the restricted range for stress see Figure 1.

\section{Correlation between the selected demographic variables vs. mental stress faced by the parents of autism children}

Correlation between the selected demographic variables vs. mental stress faced by the parents of autism children are presented in Table 4 . There is a significant relationship between age and financial burden, depression, treating the child in the same way at all the time at five per cent level. There is a significant relationship between the sex and the level of stress in consequences to child's misbehavior at one per cent level, stress and difficulty in balancing responsibilities at 5 per cent level.

Showing angriness when the child misbehaves, annoyance and difficulty in balancing responsibilities had a significant relationship for religion at 5 per cent level. There is a significant relationship between community and depression, showing angriness, treating the child in the same way at all the time and satisfied as a parent at five per cent level [8].

Type of family had significant relationship between consequences to child's misbehavior, depression and difficulty in balancing responsibilities at 5 per cent level.

\begin{tabular}{|l|c|}
\hline Aspects & $\begin{array}{c}\text { Percentage of } \\
\text { Respondents (N: 50)* }\end{array}$ \\
\hline Find the right school or right type of education & 80 \\
\hline Enjoy leisure and recreational opportunities & 52 \\
\hline $\begin{array}{l}\text { Travel safely and independently begin or maintain a } \\
\text { friendship or a relationship }\end{array}$ & 52 \\
\hline From school to college or in to employment & 48 \\
\hline Maintain a balanced healthy and nutritious diet & 40 \\
\hline Source: Field survey 2017, *Multiple responses. & \\
\hline
\end{tabular}

Table 2: Difficulties faced by the parents due to their autism children.

\begin{tabular}{|l|c|c|}
\hline Level of stress & Frequency & Percentage \\
\hline Low (less than 48) & 16 & 32 \\
\hline Moderate (48-57) & 22 & 44 \\
\hline High (above 57) & 12 & 24 \\
\hline
\end{tabular}

Table 3: Level of stress faced by the parents of autism children. 
Citation: Kalaivnai P, Kalimo KM (2018) A Study on Psychological Problems Faced by the Parents of Autism Children. Arts Social Sci J 9: 376 . doi: 10.4172/2151-6200.1000376

Page 3 of 5

There is a significant relationship between occupation and annoyance at one per cent level, source of stress, depression and stress at 5 per cent level. Income of the respondents had relationship between depression and treating the child in the same way at all the time at one per cent level.

\section{Level of adjustment among the parents towards their autism children}

The level of adjustment among the parents towards their autism

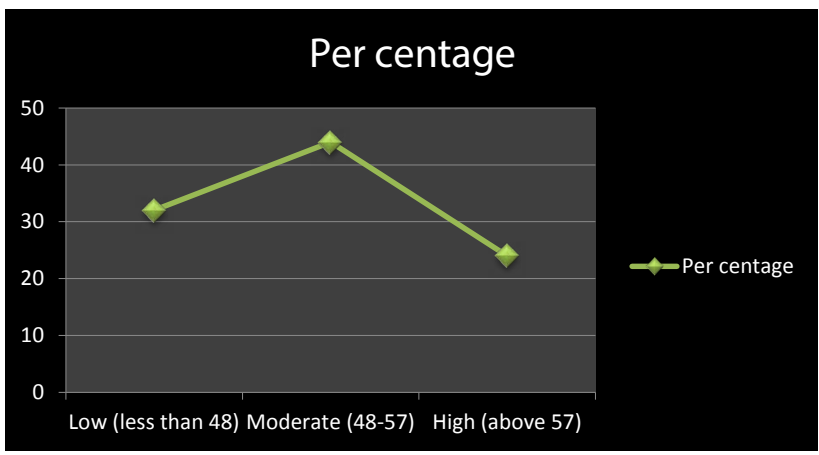

Figure 1: Level of stress faced by the parents of autism children.

\begin{tabular}{|c|c|c|c|}
\hline \multirow[t]{2}{*}{ Factors of Mental Stress } & \multirow[b]{2}{*}{ Age (in yrs) } & \multirow[b]{2}{*}{ Sex } & \multirow[b]{2}{*}{ Religion } \\
\hline & & & \\
\hline \multirow[t]{2}{*}{ Happiness in their role as parent } & 0.657 & 0.084 & 0.321 \\
\hline & 0.064 & 0.246 & 0.143 \\
\hline \multirow{2}{*}{$\begin{array}{l}\text { More amount of time and energy takes for spending with } \\
\text { children }\end{array}$} & 0.455 & 0.462 & 0.035 \\
\hline & 0.108 & 0.106 & 0.298 \\
\hline \multirow[t]{2}{*}{ Worry due to doing enough for their children } & 0.112 & 0.286 & 0.238 \\
\hline & 0.227 & 0.154 & 0.139 \\
\hline \multirow[t]{2}{*}{ Source of stress } & 0.139 & 0.317 & 0.404 \\
\hline & 0.212 & 0.144 & 0.121 \\
\hline \multirow[t]{2}{*}{ consequences to child's misbehaviour } & 0.203 & $0.969^{\star *}$ & 0.609 \\
\hline & 0.183 & 0.006 & 0.074 \\
\hline \multirow[t]{2}{*}{ Financial burden } & $0.946^{*}$ & 0.154 & 0.65 \\
\hline & 0.01 & 0.204 & 0.066 \\
\hline \multirow[t]{2}{*}{ Quarrel with the child for their behaviour and attitude } & 0.669 & 565 & 0.207 \\
\hline & 0.062 & 0.083 & 0.182 \\
\hline \multirow[t]{2}{*}{ Depression } & $0.899^{*}$ & 0.492 & 0.028 \\
\hline & 0.018 & 0.1 & 0.311 \\
\hline \multirow[t]{2}{*}{ Stress } & 0.35 & $0.780^{*}$ & 0.021 \\
\hline & 0.135 & 0.04 & 0.325 \\
\hline \multirow[t]{2}{*}{ Showing angriness } & 0.217 & 0.507 & $0.739^{*}$ \\
\hline & 0.178 & 0.096 & 0.048 \\
\hline \multirow[t]{2}{*}{ Giving punishment to the child } & 0.831 & 0.737 & 0.158 \\
\hline & 0.031 & 0.049 & 0.203 \\
\hline \multirow[t]{2}{*}{ Treating the child in a same way all the time } & $0.746^{*}$ & 0.561 & 0.098 \\
\hline & 0.047 & 0.084 & 0.237 \\
\hline \multirow[t]{2}{*}{ Annoyance } & 0.372 & 0.461 & $0.679^{*}$ \\
\hline & 0.129 & 0.107 & 0.06 \\
\hline \multirow[t]{2}{*}{ Difficulty in balancing responsibilities } & 0.583 & $0.782^{*}$ & $0.889^{*}$ \\
\hline & 0.08 & 0.04 & 0.02 \\
\hline \multirow[t]{2}{*}{ Satisfaction as a parent } & 0.236 & 0.25 & 0.088 \\
\hline & 0.171 & 0.166 & 0.244 \\
\hline
\end{tabular}

children is presented in Table 5. Thirteen respondents (26 per cent) had a score of less than 31(low level of adjustment), twenty seven respondents ( 56 per cent) had a score between 31 and 41 (moderate level of adjustment), and 10 respondents ( 20 per cent) had a score of greater than 41(high level of adjustment). The range of scores inthe present study shows thatmore than 50 per cent of the parents had moderate level of adjustment with their autism children. For a visual depiction of the level of adjustment see Figure 2.

Correlation between the selected demographic variables vs. level of adjustment among the parents towards their autism children

The correlation between the selected demographic variables vs. level of adjustment among the parents towards their autism children is presented in Table 6 .

There is a significant relationship between the age and satisfying the child's necessary needs, doing child's work and satisfying child wants at five per cent level. There is a significant relationship between the religion and the level of adjustment in in enjoyment in spending time with childe at one per cent level and feeling of closeness at 5 per cent level [9].

Satisfying the child's necessary needs and having chalt/talk had a significant relationship with community at one per cent level, whereas p value

\begin{tabular}{|c|c|c|c|c|} 
Community & Family type & Education & Occupation & Income
\end{tabular}

\begin{tabular}{|l|l|l|l|l|}
\hline 0.112 & 0.1 & 0.274 & 0.227 & 0.201 \\
\hline
\end{tabular}

\begin{tabular}{|l|l|l|l|l|}
\hline 0.013 & 0.229 & 0.16 & 0.467 & 0.409 \\
\hline
\end{tabular}

\begin{tabular}{|l|l|l|l|l|}
\hline 0.35 & 0.173 & 0.167 & 0.105 & 0.119 \\
\hline
\end{tabular}

\begin{tabular}{l|l|l|l|l}
0.841 & 0.018 & 0.247 & 0.818 & 0.102
\end{tabular}

\begin{tabular}{|l|l|l|l|l|}
\hline 0.029 & 0.333 & 0.167 & 0.033 & 0.234 \\
\hline
\end{tabular}

\begin{tabular}{|l|l|l|l|l|}
\hline 0.675 & 0.034 & 0.165 & $0.849^{*}$ & 0.171 \\
\hline
\end{tabular}

\begin{tabular}{|l|l|l|l|l|}
\hline 0.061 & 0.301 & 0.2 & 0.028 & 0.197
\end{tabular}

\begin{tabular}{|l|l|l|l|l|}
\hline 0.626 & $0.757^{*}$ & 0.002 & 0.673 & 0.068 \\
\hline
\end{tabular}

\begin{tabular}{|l|l|l|l|l|}
\hline 0.071 & 0.045 & 0.433 & 0.061 & 0.261 \\
\hline
\end{tabular}

\begin{tabular}{|l|l|l|l|l|}
\hline 0.563 & 0.448 & 0.597 & 0.29 & 0.349 \\
\hline
\end{tabular}

\begin{tabular}{|l|l|l|l|l|}
\hline 0.084 & 0.11 & 0.077 & 0.153 & 0.135 \\
\hline
\end{tabular}

$0.487 \quad 0.281$

\begin{tabular}{|l|l|l|l|l|}
\hline 0.17 & 0.133 & 0.318 & 0.101 & 0.156 \\
\hline
\end{tabular}

\begin{tabular}{|l|l|l|l|l|}
\hline $0.882^{*}$ & $0.821^{*}$ & 0.188 & $0.843^{*}$ & $0.000^{* *}$ \\
\hline
\end{tabular}

\begin{tabular}{l|l|l|}
\hline 0.019 & 0.033 & 0.189 \\
\hline
\end{tabular}

\begin{tabular}{l|l|l}
\hline 0.896 & 0.238 & 0.153 \\
\hline
\end{tabular}

\begin{tabular}{l|l|l|}
\hline 0.019 & 0.17 & 0.205 \\
\hline
\end{tabular}

Table 4: Correlation between the selected demographic variables vs. mental stress faced by the parents of autism children. 
Citation: Kalaivnai P, Kalimo KM (2018) A Study on Psychological Problems Faced by the Parents of Autism Children. Arts Social Sci J 9: 376 . doi: 10.4172/2151-6200.1000376

Page 4 of 5

\begin{tabular}{|c|c|c|}
\hline Level of adjustment & Frequency & Percentage \\
\hline Low (less than 31) & 13 & 26 \\
\hline Moderate (31-41) & 27 & 54 \\
\hline High (above 41) & 10 & 20 \\
\hline
\end{tabular}

Table 5: Level of adjustment among the parents towards their autism children.

\begin{tabular}{|c|c|c|c|c|c|c|c|c|}
\hline \multirow[t]{2}{*}{ Level of adjustment and concern } & \multicolumn{8}{|c|}{$p$ value } \\
\hline & Age (in yrs) & Sex & Religion & Community & Family type & Education & Occupation & Income \\
\hline \multirow[t]{2}{*}{ Satisfying the child's necessary needs } & $0.801^{*}$ & 0.301 & 0.584 & $0.977^{* *}$ & 0.034 & $0.977^{* *}$ & 0.287 & $0.834^{*}$ \\
\hline & 0.036 & 0.149 & 0.079 & 0.004 & 0.301 & 0.004 & 0.157 & 0.03 \\
\hline \multirow[t]{2}{*}{ Doing child's work } & $0.747^{*}$ & 0.001 & 0.806 & 0.563 & 0.662 & 0.372 & 0.014 & 0.005 \\
\hline & 0.047 & 0.453 & 0.036 & 0.084 & 0.063 & 0.129 & 0.345 & 0.39 \\
\hline \multirow[t]{2}{*}{ Praising the behaviour of the child } & 0.584 & 0.013 & 0.584 & 0.574 & 0.615 & 0.659 & 0.042 & 0.021 \\
\hline & 0.079 & 0.348 & 0.079 & 0.081 & 0.073 & 0.064 & 0.289 & 0.325 \\
\hline \multirow[t]{2}{*}{ Feeling of proudness } & 0.524 & 0.088 & 0.032 & $0.764^{*}$ & $0.778^{*}$ & 0.011 & 0.211 & 0.155 \\
\hline & 0.092 & 0.244 & 0.303 & 0.044 & 0.041 & 0.358 & 0.18 & 0.204 \\
\hline \multirow[t]{2}{*}{ Teamwork with partner in parenting } & 0.026 & 0.237 & 0.554 & 0.095 & 0.108 & 0.088 & 0.024 & 0.02 \\
\hline & 0.314 & 0.17 & 0.086 & 0.239 & 0.23 & 0.244 & 0.318 & 0.328 \\
\hline \multirow[t]{2}{*}{ Enjoyment in spending time with child } & 0.384 & 0.008 & $.948^{* *}$ & 0.289 & 0.563 & 0.213 & 0.062 & 0.362 \\
\hline & 0.126 & 0.372 & 0.009 & 0.153 & 0.084 & 0.179 & 0.314 & 0.132 \\
\hline \multirow[t]{2}{*}{ Feeling of happiness } & 0.544 & 0 & 0.55 & 0.362 & $.932^{*}$ & 0.005 & 0.007 & 0.014 \\
\hline & 0.088 & 0.53 & 0.087 & 0.132 & 0.012 & 0.394 & 0.374 & 0.344 \\
\hline \multirow[t]{2}{*}{ Satisfying the child's wants } & $0.977^{* *}$ & 0.001 & 0.464 & 0.517 & 0.834 & 0.034 & 0.009 & 0.161 \\
\hline & 0.004 & 0.442 & 0.106 & 0.094 & 0.03 & 0.301 & 0.366 & 0.201 \\
\hline \multirow[t]{2}{*}{ Having chat/talk with the child } & 0.301 & 0.002 & 0.613 & $0.958^{* *}$ & 0.597 & 0.673 & 0.014 & 0.223 \\
\hline & 0.149 & 0.434 & 0.073 & 0.008 & 0.077 & 0.061 & 0.347 & 0.178 \\
\hline \multirow[t]{2}{*}{ Feeling of closeness } & 0.359 & 0 & $.696^{*}$ & 0.425 & 0.287 & 0.155 & 0.024 & 0.021 \\
\hline & 0.133 & 0.494 & 0.057 & 0.115 & 0.157 & 0.204 & 0.319 & 0.326 \\
\hline \multirow[t]{2}{*}{ Flexibility provides by child in their life } & 0.378 & 0 & 0.406 & $0.948^{*}$ & $0.900^{*}$ & 0.01 & 0.011 & 0.007 \\
\hline & 0.127 & 0.491 & 0.12 & 0.01 & 0.018 & 0.361 & 0.358 & 0.377 \\
\hline \multirow[t]{2}{*}{ Main source of their affection } & 0.002 & 0.002 & 0.088 & $0.755^{*}$ & $0.817^{*}$ & 0.613 & 0.116 & $0.817^{*}$ \\
\hline & 0.423 & 0.423 & 0.244 & 0.045 & 0.034 & 0.073 & 0.225 & 0.034 \\
\hline
\end{tabular}

Table 6: Correlation between the selected demographic variables vs. level of adjustment among the parents towards their autism children.

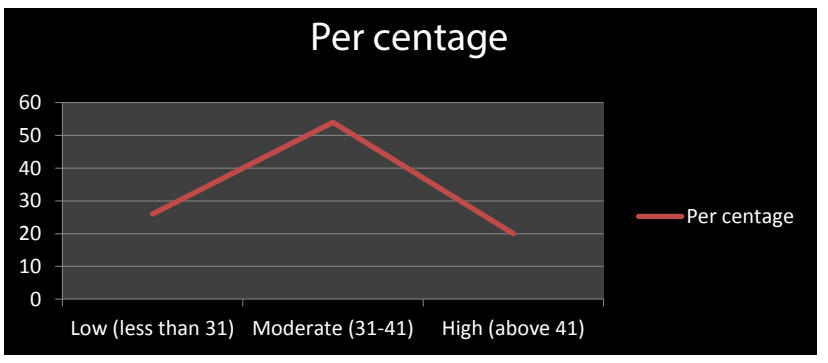

Figure 2: Level of adjustment among the parents towards their autism children.

proud feelings, flexibility and considering child as the main source of their affection had a significant relationship with community at 5 per cent level.

Type of family had significant relationship between proud feelings, feeling of happiness, flexibility and considering child as the main source of their affection at 5 per cent level.

There is a significant relationship between education and satisfying the child's necessary needs at one per cent level. Income of the respondents had relationship between satisfying the child's necessary needs and considering child as the main source of their affection at 5 per cent level [10]. There is no relationship between sex and occupation with the level of adjustment among the parents towards their autism children.

\section{Suggestions}

1. The parents have to spend more time with their autism children for their betterment.

2. The parents and other family members allow their autism children to play with the other children.

3. No restriction from the parents, other family members, and the outside environment in play and activities of the autism children.

4. To encourage the interests and talents of the autism children.

5. The parents have to treat the autism children as ordinary children.

\section{Conclusion}

It is revealed that parents who have an autism child had undergone multiple challenges in various aspects of care, impacting or had influence or parents' stress and adaption. Delays in communication and language development are apparent early in life in ASD children, and emphasizes that for delays in gesture, developmental surveillance, which may be among the earliest signs of ASD were confirmed $[11,12]$.

There is a dire to need to spread awareness among local masses specifically parents to get sensitize about the alarming disorder so to come forward and have exposure of different remedial measures which helps to bring holistic changes in ASD children. Most of the 
parents have facing problems in finding the right school or right type of education for their autism children. However, it was concluded that parent's ability and confidence in their competence of parenting a child in challenging situations may reduce their stress to a limited extent.

\section{References}

1. Kim (2015) Recent update of autism spectrum disorders, Korean Journal of Pediatrics 58: 8-14.

2. Hoefman R, Payakachat N, van Exel J, Kuhlthau K, Kovacs E, et al. (2014) Caring for a Child with Autism Spectrum Disorder and Parents' Quality of Life: Application of the Carerqol. Journal of Autism Developmental Disorder 44: 1933-1945.

3. Ludlow A, Skelly C, Rohleder P (2012) Challenges Faced by Parents of Children Diagnosed with Autism Spectrum Disorder. J Health Psychol 17: 702-711.

4. Bonis S (2016) Stress and Parents of Children with Autism: A Review of Literature, J Issues Ment Health Nurs 37: 153-163.

5. Burge $P$, Ouellette-Kuntz H, Isaacs B, Lunsky $Y$ (2008) Medical students' views on training in intellectual disabilities Canadian Family Physician 54: 568-569.

6. Cooper SA, Smiley E, Morrison J, Williamson A, Allan L, et al. (2007) Mental ill- health in adults with intellectual disabilities: prevalence and associated factors. The British Journal of Psychiatry 27: 35-25.

7. Hodgetts S, Nicholas D, Zwaigenbaum L (2013) Home sweet home? Families experiences with aggression in children with autism spectrum disorders Focus on Autism and Other Developmental Disabilities 1-9.

8. Lecavalier L, Leone S, Wiltz J (2006) The impact of behavior problems on caregiver stress in young people with autism spectrum disorders. Journal of Intellectual Disability Research, pp: 172-183.

9. Lecavalier L (2006) Behavioral and emotional problems in young people with pervasive developmental disorders: Relative prevalence effects of subject characteristics and empirical classification. Journal of Autism and Developmental Disorders, pp: 1101-1114.

10. Mandell DS (2008) Psychiatric hospitalization among children with autism spectrum disorders. Journal of Autism and Developmental Disorders 38: 10591065.

11. Mazurek MO, Kanne SM, Wodka EL (2013) Physical aggression in children and adolescents with autism spectrum disorders. Research in Autism Spectrum Disorders, pp: 455-465.

12. Hus V, Bishop S, Gotham K, Huerta M, Lord C, et al. (2013) Factors influencing scores on the Social Responsiveness Scale. Journal of Child Psychology and Psychiatry 54: 216-224. 